\title{
KOMUNIKASI ORGANISASI PT. PLN (PERSERO) AREA BANDUNG DALAM KEGIATAN CODE OF CONDUCT
}

\author{
Rara Ayu Mulia Murti ${ }^{1}$, Martha Tri Lestari ${ }^{2}$, dan Dini Salmiyah Fithrah Ali ${ }^{3}$ \\ 1,2,3Universitas Telkom
}

\begin{abstract}
ABSTRAK
Komunikasi terjadi dalam suatu situasi tertentu, salah satunya adalah komunikasi organisasi. Sebuah organisasi pastinya akan memerlukan komunikasi, karena digunakan sebagai alat untuk memperlancar jalannya kegiatan dan guna mencapai tujuan yang telah ditetapkan oleh organisasi. PT. PLN (Persero) merupakan perusahaan dengan tugas utama menyediakan tenaga listrik bagi kepentingan umum. Sebagai perusahaan besar, PT. PLN (Persero) berkewajiban untuk selalu prima dalam hal kinerja dan pelayanan pelanggan. Oleh karena itu, PT. PLN (Persero) Area Bandung menyadari bahwa perlu adanya langkah nyata untuk meningkatkan kinerja karyawan dengan melakukan penguatan koordinasi antarfungsional dengan membuat kegiatan Code of Conduct yang diadakan di kantor PT. PLN (Persero) Area Bandung setiap hari Selasa. Code of Conduct dalam pelaksanaannya sangat berguna untuk meningkatkan koordinasi seluruh karyawan dalam menjalankan tugas sehari-hari maupun tugas lainnya. Tujuan penelitian ini adalah untuk mengetahui komunikasi organisasi PT. PLN (Persero) Area Bandung dalam kegiatan Code of Conduct. Penelitian ini bersifat kualitatif dengan pendekatan studi kasus yang akan diuraikan secara deskriptif. Berdasarkan hasil observasi partisipatif dan wawancara mendalam, proses komunikasi dalam kegiatan Code of Conduct berlangsung secara two ways communication dengan arah aliran informasi yang terjadi yaitu komunikasi ke bawah, komunikasi ke atas, dan komunikasi horizontal sehingga pola jaringan komunikasi organisasi yang terbentuk adalah pola jaringan saluran bebas (all channel).
\end{abstract}

Kata-kata Kunci: PT. PLN (Persero) area bandung, kegiatan code of conduct, komunikasi organisasi, arah aliran informasi, pola jaringan komunikasi organisasi

\section{ORGANIZATIONAL COMMUNICATION PT. PLN (PERSERO) AREA BANDUNG IN CODE OF CONDUCT ACTIVITY}

\begin{abstract}
Communication Occurs in a given situation, which one is organizational communication.. An organization will certainly require communication because It is used as a tool for the smooth running of activities and in order to achieve the goals set by the organization. PT. PLN (Persero) is a company with the main task of providing electricity to the public interest. As a big company, PT. PLN (Persero) Area Bandung is obliged to always excellent in terms of performance and customer service. Therefore, PT. PLN (Persero) Area Bandung realize that the need for concrete steps for Enhance employee performance by strengthening coordination functional with others functional by making the Code of Conduct activity that held at the office of PT. PLN (Persero) Area Bandung every Tuesday. Code of Conduct activity in practice is very useful to improve the coordination of all employees in performing everyday tasks as well as other tasks. The purpose of this study was to Determine the organizational communication PT. PLN (Persero) Bandung Area Bandung in Code of Conduct activity. This study is a qualitative case study approach will be Described descriptively. Based on the results of participant observation and interviews, the process of communication in the Code of Conduct activity took place in two-way communication with the direction of flow of information that occurred downward communication, upward communication, and communication horizontally so that the pattern of communication network organization that is formed is a network pattern-free channels (all channels).
\end{abstract}

Keywords: PT. PLN (Persero) bandung area, code of conduct's activity, communication organization, directions flow of information, pattern of communication organization

Korespondensi: Rara Ayu Mulia Murti, S.Ikom. Program Studi Ilmu Komunikasi, Fakultas Komunikasi dan Bisnis, Universitas Telkom, Jl. Telekomunikasi Terusan Buah Batu, Bandung 40257.Email: muliamurti@, gmail.com 


\section{PENDAHULUAN}

Komunikasi selalu muncul dalam konteks, yakni dalam suatu situasi tertentu. Secara teoritis, konteks komunikasi dibedakan menurut bebrapa kategori yaitu salah satunya berdasarkan jumlah partisipan dalam kegaiatan komunikasi, disebut tataran komunikasi. Sesuai yang tertulis dalam buku Ilmu Komunikasi (Daryanto,2011: 29) tataran komunikasi meliputi komunikasi intrapribadi, komunikasi antarpribadi, komunikasi kelompok, komunikasi publik, komunikasi massa, dan komunikasi organisasi.

PT. PLN (Persero) merupakan perusahaan yang pada awal berdirinya ditetapkan sebagai Perusaahaan Umum dengan status Pemegang Kuasa Usaha Ketenagalistrikan (PKUK) sesuai dengan Peraturan Pemerintah No. 17 tahun 1972. Namun seiring dengan kebijakan Pemerintah yang memberikan kesempatan kepada sektor swasta untuk bergerak dalam bisnis penyediaan tenaga listrik, maka sejak tahun 1994 status PLN (Persero) beralih dari Perusahaan Umum menjadi Perusahaan Perseroan sesuai Akta nomor 169 tanggal 13 Juli 1994 dari Sutipto S.H. Notaris, Jakarta. Pada tahun 2009, sesuai dengan UU No. 30 Tahun 2009, PLN (Persero) tidak lai sebagai Pemegang Kuasa Usaha Ketenagalistrikan (PKUK) tapi sebagai perusahaan BUMN dengan tugas utama menyediakan tenaga listrik bagi kepentingan umum (Company Profile PT. PLN (Persero), 2011).

PT. PLN (Persero) berhasil menunjukan prestasinya dengan diakuinya mereka sebagai perusahaan besar menurut survey yang dilakukan oleh salah satu majalah bisnis skala Internasional yaitu Fortune Magazine Edisi Tahun 2014. Seperti yang dilansir oleh (Fortune Magazine, 2014) PT. PLN (Persero) berhasil dinobatkan menjadi perusahaan besar dunia peringkat 477 dengan relatif usia yang masih muda. Menurut data yang disajikan, PT. PLN (Persero) mampu mendapatkan total pendapatan bersih sebesar Rp 257,4 Trilliun Rupiah sepanjang tahun 2014.

Namun prestasi membanggakan tersebut harus tercoreng dengan banyaknya sorotansorotan negatif terhadap kinerja PT. PLN (Persero). Pertama, publik menyoroti kurangnya pengawasan dan pemeliharaan untuk jaringan listrik, banyak kabel-kabel dengan tegangan listrik tinggi tidak dalam posisi sebenarnya yang dapat mengurangi keindahaan dan membahayakan keselamatan masyarakat dan petugas lapangan PT. PLN (Persero). Kedua adalah sering terjadinya pemadaman listrik yang sangat merugikan masyarakat dan waktu penanganan terhadap pemadaman yang dirasa lama semakin menambah kerugian masyarakat. Ketiga adalah naiknya tarif tenaga listrik yang terkadang dirasa terlalu tiba-tiba dan tidak berorientasi pada rakyat kecil. Corengan ini berkaitan dengan citra perusahaan, dan citra tersebut tentu dibangun salah satunya melalui kegiatan/program yang dilakukan (Nurussa'adah \& Sumartias, 2017).

Dengan banyaknya permasalahan yang dialami oleh PT. PLN (Persero) membuat tingkat kinerja PT. PLN (Persero) kurang jika dibandingkan perusahaan-perusahaan besar BUMN lainnya. Menurut data yang didapat dari (Majalah Invonesia, 2014), PT. PLN (Persero) hanya meraih posisi ke-10 pada tahun 2014 untuk perusahaan BUMN terbaik dari segi kinerja, pelayanan pelanggan, pendapatan, penanganan terhadap masalah perusahaan yang dapat dilihat pada tabel 1 .

\section{Tabel 1 Perusahaan BUMN dengan Kinerja Terbaik Tahun 2015}

\begin{tabular}{ll}
\hline No & Nama Perusahaan BUMN \\
\hline 1 & $\begin{array}{l}\text { PT. Telekomunikasi Indonesia (Persero), } \\
\text { Tbk }\end{array}$ \\
\hline 2 & PT. Bank Mandiri (Persero), Tbk \\
\hline 3 & PT. Bank Rakyat Indonesia (Persero), Tbk \\
\hline 4 & PT. Bank Negera Indonesia (Persero), Tbk \\
\hline 5 & PT. Garuda Indonesia (Persero), Tbk \\
\hline 6 & PT. Bio Farma (Persero) \\
\hline 7 & PT. Semen Indonesia (Persero), Tbk \\
\hline 8 & PT. Angkasa Pura (Persero) \\
\hline 9 & PT. Pertamina (Persero) \\
\hline 10 & PT. Perusahaan Listrik Negara (Persero) \\
Sumber: Majalah Invonesia, 2015
\end{tabular}

Baik kinerja, pelayanan pelanggan, dan penyelesaian masalah pada perusahaan tentu semua melibatkan karyawan di dalamnya. Karyawan sebagai aktor utama penentu tumbuh dan kembangnya sebuah perusahaan ke arah yang lebih baik ini perlu melakukan perbaikan diri. Hal itu selaras dengan budaya perusahaan PT. PLN (Persero) sendiri yang 
menempatkan karyawan sebagai fokus utama dalam melancarkan jalannya kegiatan bisnis perusahaan, maka karyawan PT. PLN (Persero) dituntut untuk selalu maksimal dalam memberikan kontribusi kinerja terbaiknya bagi perusahaan. Dalam mensukseskan perbaikan diri karyawan ini, maka harus melibatkan PT. PLN (Persero) kantor Area dan kantor Unit yang tersebar di seluruh Indonesia, hal tersebut dikarenakan dalam pelaksanaan tugasnya yang lebih berhubungan dengan pelanggan adalah kantor PT. PLN (Persero) Area dan PT. PLN (Persero) kantor Unit.

PT. PLN (Persero) Area Bandung yang terletak di Jalan Soekarno Hatta No. 436 Bandung ini merupakan kantor pusat PT. PLN (Persero) untuk wilayah Bandung. Sebagai kantor pusat Bandung, maka PT. PLN (Persero) Area Bandung memiliki tanggung jawab lebih untuk memberikan kinerja terbaiknya bagi perusahaan dan pelanggan secara umumnya. Sebagai perusahaan yang dalam melakukan pekerjaannya membutuhkan kerja sama dari seluruh fungsional yang ada, mengharuskan PT. PLN (Persero) Area Bandung memiliki tingkat kordinasi yang baik. Salah satu langkah dalam meningkatkan koordinasi demi melancarkan pekerjaan adalah dengan memperlancar arus komunikasi antarfungsional yang ada. Langkah nyata yang dilakukan PT. PLN (Persero) Area Bandung untuk memperlancar arus komunikasi antar fungsional adalah melakukan kegiatan yang dinamakan Code of Conduct.

Menurut hasil wawancara dengan Bapak Dony selaku Supervisor Administrasi PT. PLN (Persero) Area Bandung tanggal 17 November 2015 pukul 13.00 WIB di Kantor PT. PLN (Persero) Area Bandung, kegiatan Code of Conduct adalah kegiatan rutin PT. PLN (Persero) Area Bandung yang di dalamnya terdapat pembekalan secara materi tentang visi \& misi perusahaan, nilai-nilai perusahaan, dan pedoman perilakuyang harus selalu dipatuhioleh seluruh karyawan. Selain terdapat pembekalan materi, dalam kegiatan Code of Conduct yang menjadi fokus perhatian karyawan adalah adanya pembahasan mengenai pekerjaan yang dapat berupa informasi mengenai pekerjaan yang akan dilakukan, kendala yang dihadapi di lapangan, dan tentang pencapaian kinerja pekerjaan. Pembahasan mengenai pekerjaan ini dilakukan dalam bentuk diskusi, dimana karyawan dapat memberikan tanggapan sesuai dengan pembahasan yang sedang dilakukan.

Observasi penelitian pola komunikasi organisasi dalam kegiatan Code of Conduct dilakukan dari tanggal 3 November 2015-24 November 2015 ditampilkan pada tabel 2.

\section{Tabel 2 Observasi Kegiatan Code of Conduct Periode November 2015}

\begin{tabular}{lll}
\hline No & Hari / Tanggal & Kegiatan Code of Conduct \\
\hline 1 & Selasa, 3 November 2015 & Kegiatan Code of Conduct dimulai dengan yel-yel yang \\
& & mengandung semangat untuk meraih pencapaian PT. PLN \\
& (Persero) Area Bandung, dilanjut pembacaan visi \& misi \\
& perusaaan, pembacaan do and don't do and don't yang \\
& merupakan pedoman perilaku karyawan, dan pembahasan \\
& knowledge sharing dengan tema kematian. \\
\hline 2 & Selasa, 17 November 2015 & Kegiatan Code of Conduct dimulai kembali dengan yel- \\
& yel semangat tentang pencapaian yang harus selalu dicapai \\
& karyawan PT. PLN (Persero) Area Bandung, dilanjut den- \\
& gan visi \& misi perusahaan, dan pembacaan tentang SIPP \\
& yang merupakan tata nilai perusahaan, dan terakhir adanya \\
& knowledge sharing tentang salah satu bagian dari PT. PLN \\
& (Persero) yaitu PDKB TM. \\
\hline Selasa, 24 November 2015 & Kegiatan Code of Conduct kembali dimulai dengan yel-yel \\
& semangat, pembacaan visi \& misi perusahaan, pembacaan \\
& tata nilai perusahaan yaitu SIPP, dan knowledge sharing \\
& tentang tidak boleh adanya gratifikasi di PT. PLN (Persero) \\
& Area Bandung. \\
\hline &
\end{tabular}

Sumber: Olahan penulis, 2015 
Komunikasi organisasi adalah komunikasi antara orang-orang dalam jabatan (posisi) yang berada dalam organisasi tersebut. Komunikasi organisasi meliputi komunikasi interpersonal (percakapan antara atasan dan bawahan), komunikasi publik (presentasi yang dilakukan oleh para eksekutif dalam perusahaan), komunikasi kecil (komunikasi antara rekan kerja dalam satu unit), dan komunikasi dengan menggunakan media (memo internal, e-mail, dan konferensi jarak jauh) (West \& Turner, 2012: 38). Selain itu, Schein juga mengungkapkan bahwa organisasi mempunyai karakteristik tertentu yang mempunyai struktur, tujuan, saling berhubungan dengan satu bagian dengan bagian lainnya dan sangat tergantung kepada komunikasi manusia untuk mengkordinasikan aktivitas dalam organisasinya (Irawan \& Venus, 2016).

Arah aliran informasi organisasi adalah informasi yang berpindah dari seseorang yang kedudukannya lebih tinggi kepada orang lain yang kedudukannya lebih rendah, dan informasi yang bergerak dari suatu jabatan yang kedudukannya lebih rendah kepada jabatan yang lebih tinggi, serta informasi yang bergerak di antara orang-orang dalam jabatan atau tingkatan yang sama, dan tidak ketinggalan informasi yang bergerak di antara orang-orang yang tidak menjadi atasan atau bawahan satu sama lainnya. Sehingga menurut (Pace dan Faulus, 2006: 183) arah aliran informasi adalah komunikasi ke bawah, komunikasi ke atas, komunikasi horizontal, dan komunikasi informal atau selentingan. Penyajian informasi yang dalam penerapannya didasari oleh kreatifitas, keindahan (daya tarik), ketepatan isi dengan ilustrasi, serta keefektifan waktu yang diperlukan Dalam menginterpretasikan informasi (Miftah, Rizal, \& Anwar, 2016).

Pola komunikasi merupakan model dari proses komunikasi, sehingga dengan adanya berbagai macam model komunikasi dan bagian dari proses komunikasi dapat ditemukan pola yang sesuai dan mudah digunakan dalam berkomunikasi (Komariah, Perbawasari, Nugraha, \& Budiana, 2013). Istilah yang digunakan untuk menggambarkan proses komunikasi yang terjadi adalah pola jaringan komunikasi organisasi. Pola jaringan komunikasi organisasi dapat dipahami sebagai bentuk atau hubungan antara dua orang atau lebih dalam pengiriman dan penerimaan pesan dengan cara yang teoat sehingga pesan yang dimaksud dapat dipahami. Dalam suatu organisasi, pola jaringan komunikasi adalah bagaimana suatu pesan termasuk arus informasi dan instruksi disampaikan secara rinci.

Menurut Ruliana (2014: 80) terdapat lima jenis pola jaringan komunikasi organisasi, yaitu: (1) Pola jaringan rantai, yaitu pola komunikasi dengan lima tingkatan hierarki sehingga hanya dikenal komunikasi sistem arus ke atas dan sistem arus ke bawah dengan menganut hubungan garis lurus tanpa terjadinya penyaringan, (2) Pola jaringan roda, yaitu pola komunikasi di mana semua laporan, instruksi, perintah kerja dan pengawasan terpusat pada satu orang pemimpin yang memimpin empat bawahan atau lebih dan diantara bawahan tidak dapat terjadi interaksi, (3) Pola jaringan lingkaran, yaitu pola komunikasi di mana semua anggota/staf bisa terjadi interaksi pada setiap tiga tingatan hierarkinya, tetapi tanpa ada kelanjutannya pada tingkatan yang lebih tinggi dan hanya terbatas pada setiap level, (4) Pola jaringan huruf $Y$, yaitu pola komunikasi dengan empat level jenjang hierarkinya. Satu supervisor mempunyai dua bawahan dan dua atasan yang mungkin berbeda divisi/departemen, dan (5) Pola jaringan saluran bebas, yaitu pola komunikasi di mana semua tingkatan dapat melakukan interaksi secara timbal balik tanpa menganut siapa yang menjadi tokoh sentralnya.

Istilah Code of Conduct adalah kode etik yang digunakan dalam bidang keguruan dan keorganisasian yang ditulis dalam bentuk dokumen yang dikeluarkan oleh asosiasi profesional, lembaga pelaksana pengawasan atau lembaga-lembaga profesi lainnya yang bertujuan untukmemberikan bimbingan perilaku bagi para anggotanya, melindungi pengguna jasa, dan menjaga reputasi profesionalitasnya (Shirley van Nuland, 2009: 19)

Kegiatan Code of Conduct merupakan satu-satunya kegiatan yang pelaksanaannya dilakukan di kantor PT. PLN (Persero) Area Bandung yang dapat mengumpulkan seluruh karyawan mulai dari tingkatan tertinggi yaitu Manajer Area, Assisten Manajer, Supervisor dan Fungsional di dalam ruang dan waktu yang sama, dengan seperti itu dalam kegiatan Code of Conduct komunikasi akan berlangsung secara variatif. Komunikasi organisasi dalam kegiatan Code of Conduct akan berlangsung mengikuti rantai formal maupun rantai informal organisasi. 
Untuk melihat komunikasi organisasi yang berlangsung, maka peneliti menggunakan arah aliran informasi sebagai dasar untuk melihat proses komunikasi yang terjadi. Arah aliran informasi terbentuk berdasarkan isi pesan yang disampaikan oleh karyawan dalam kegiatan Code of Conduct.

Untuk lebih menjelaskan tentang alur komunikasi organisasi yang terjadi dalam kegiatan Code of Conduct PT. PLN (Persero) Area Bandung, maka peneliti akan menggamabarkannya ke dalam pola komunikasi organisasi. Arah aliran informasi dalam organisasi, dan pola komunikasi organisasi termasuk ke dalam proses komunikasi organisasi, sehingga penelitian ini diberi judul "Komunikasi Organisasi PT. PLN (Persero) Area Bandung dalam Kegiatan Code of Conduct".

\section{METODE PENELITIAN}

Paradigma yang digunakan dalam penelitian ini adalah paradigma interpretatif. Paradigma Interpretatif menurut Nasrullah (2014: 163) mempunyai asumsi bahwa kehidupan sosial didasarkan pada interaksi sosial dan sistem makna sosial dibangun bersifat subjektif karena realitas sosial didasarkan pada definisi seseorang tentang hal tersebut. Dalam paradigma interpretatif data yang didapat mampu membuka peluang untuk nantinya diterjemahkan atau dimaknai sebagaimana yang didapat oleh peneliti di lapangan.

Penelitian ini menggunakan metode kualitatif deskriptif. Pengertian deskriptif menurut (Kriyantono, 2009: 67) adalah penelitian dengan membuat deskripsi secara sistematis, faktual, dan akurat tentang faktafakta dan sifat-sifat populasi atau objek tertentu. Sementara menurut (Rakhmat, 2009: 2425) metode deskriptif hanyalah memaparkan situasi atau peristiwa bukan mencari atau menjelaskan hubungan, tidak menguji hipotesis atau membuat prediksi. Ciri dari deskriptif ialah titik berat pada observasi dan suasana alamiah (naturalistis setting).

Teknik analisis data yang dilakukan adalah reduksi data, penyajian data, dan penarikan kesimpulan. Reduksi data merupakan proses berpikir sensitif yang memerlukan kecerdasan dan keluasan dan kedalaman wawasan yang tinggi. Sugiyono dalam bukunya Memahami
Penelitian Kulitatif (2014: 92) mengatakan dalam melakukan penelitian, data yang diperoleh dari lapangan jumlahnya cukup banyak, untuk itu maka perlu dicatat secara teliti dan rinci. Untuk itu perlu segera dilakukan analisis data melalui reduksi data. Mereduksi data berarti merangkum, memilih hal-hal yang pokok, memfokuskan pada hal-hal yang penting, dicari tema dan polanya.

Setelah data direduksi, maka langkah selanjutnya adalah melakukan penyajian data. Dalam penelitian kualitatif, penyajian data bisa dilakukan dalam bentuk uraian singkat, bagan, hubungan antar kategori, flowchart, dan sejenisnya.

Langkah ketiga dalam analisis data kualitatif adalah penarikan kesimpulan dan verifikasi. Kesimpulan adalah merupakan temuan baru yang sebelumnya belum pernah ada. Temuan dapat berupa deskripsi atau gambaran suatu objek yang sebelumnya masih remang-remang atau gelap sehingga setelah diteliti menjadi jelas, dapat berupa kausal atau interaktif, hipotesis atau teori.

\section{HASIL DAN PEMBAHASAN}

Dari hasil penelitian dalam kegiatan Code of Conduct Pt. PLN (Persero) Area Bandung komunikasi berlangsung tanpa menganut komunikasi ke bawah dan komunikasi ke atas. Komunikasi hanya berlangsung secara horizontal antara bagian fungsional dan bagian fungsional lainnya. Berikut adalah penyajian hasil penelitian yang didapatkan peneliti berdasarkan teknik wawancara dengan para informan.

Pola komunikasi digunakan dalam menggambarkan proses komunikasi yang sebenar-benarnya terjadi. Dalam sebuah organisasi, pola komunikasi memudahkan peneliti dalam melihat dan menganalisa keseluruhan proses komunikasi yang terjadi dalam organisasi ataupun perusahaan. Dalam penelitian ini, pola jaringan komunikasi organisasi difokuskan pada kegiatan Code of Conduct PT. PLN (Persero) Area Bandung. Sebelum masuk ke dalam hasil penelitian mengenai pola jaringan komunikasi organisasi dalam kegiatan Code of Conduct, peneliti terlebih dahulu menjelaskan menganai sejarah terbentuknya kegiatan Code of Conduct di PLN (Persero). 
Berdasarkan buku pedoman perilaku PT. PLN (Persero) sejarah terbentuknya kegiatan Code of Conduct PT. PLN (Persero) bermula pada tahun 2009 ketika PT. PLN (Persero) mempunyai keinginan untuk menjadikan PT. PLN (Persero) sebagai perusahaan listrik besar skala ASEAN mengalahkan Perusahaan Listrik Malaysia yaitu TNB, Tenaga Nasional Berhad. PT. PLN (Persero) secara matang melakukan perencanaan untuk mendukung keinginan menjadikan PT. PLN (Persero) sebagai perusahaan listrik terbaik di Asia Tenggara dengan membentuk rancangan kegiatankegiatan yang merupakan implementasi perubahan sikap dan mindset karyawan. disepakatinya adanya kegiatan Code of Conduct yang sekarang menjadi salah satu kegiatan yang harus ada di seluruh kantor PT. PLN (Persero) seluruh Indonesia dengan harapan untuk menyukseskan perubahan mindset pendukung visi dan kinerja unggul.

Sebelum masuk ke dalam pola komunikasi organisasi, peneliti akan menguraikan dan mendeskripsikan terlebih dahulu proses komunikasi organisasi dalam kegiatan Code of Conduct ke dalam arah aliran informasi. Arah aliran informasi berguna untuk melihat alur komunikasi mengikuti alur formal dan mengikuti alur informal dalam suatu organisasi atau perusahaan. Arah aliran informasi organisasi

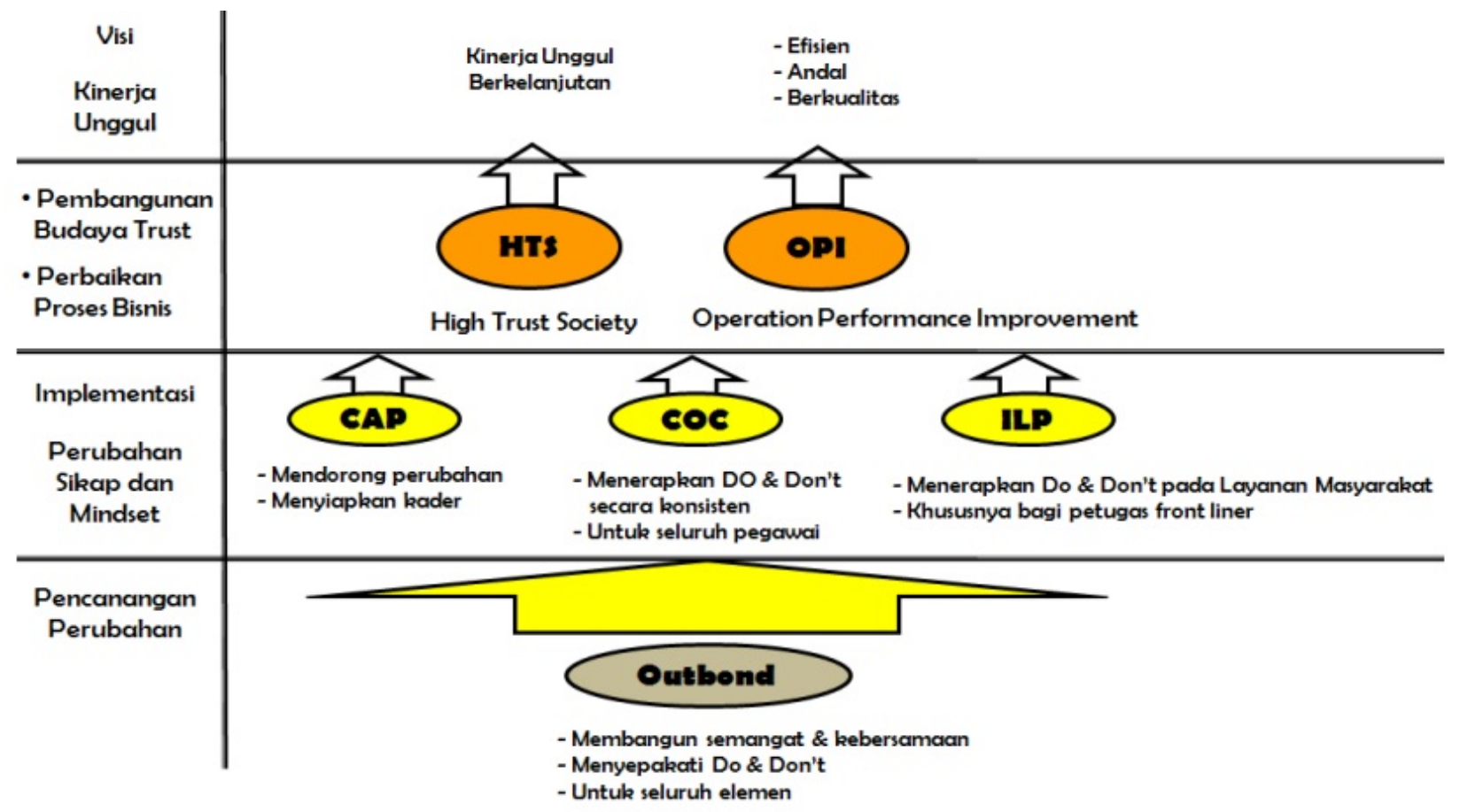

Sumber: PT. PLN (Persero), 2010

\section{Gambar 1 Alur Terbentuknya Kegiatan Code of Conduct}

Dalam skema tersebut jelas terlihat bahwa kegiatan Outbound merupakan langkah awal PT. PLN (Persero) dalam perencanaan perubahan. Kegiatan Outbound ini lah yang menjadi awal munculnya kegiatan-kegiatan yang merupakan implementasi perubahan sikap dan mindset. Jelasnya pada tahun 2010, PT. PLN (Persero) membuat kegiatan Outbound dengan mengharuskan seluruh karyawannya ikut serta dalam kegiatan, hal itu karena PT. PLN (Persero) menginginkan kegiatan Outbound yang menyenangkan tersebut dapat membangun semangat dan kebersamaan karyawan. Salah satu hasil nyata dari diadakannya kegiatan Outbound oleh PT. PLN (Persero) adalah akan seputar tentang komunikasi ke bawah, komunikasi ke atas, komunikasi horizontal, atau bahkan memungkinkan komunikasi terjadi melewati jalur formal organisasi yaitu komunikasi informal, pribadi, dan selentingan.

Komunikasi ke bawah adalah komunikasi yang memungkinkan seseorang dengan otoritas jabatan tinggi memberikan informasi kepada seseorang dengan otoritas yang lebih rendah. Walaupun di PT. PLN (Persero) Area Bandung, tingkatan tertinggi berdasarkan struktural perusahaan adalah Manajer Area, namun dalam praktek kegiatan Code of Conduct tidak terjadi komunikasi ke bawah. Hal tersebut karena karyawan menganggap bahwa dalam kegiatan 
Code of Conduct karyawan hanya berperan sebagai pelaksana kegiatan dan peserta kegiatan bukan berdasarkan posisi jabatan mereka dalam struktural organisasi sehingga tidak adanya alur komunikasi ke bawah yang memiliki ciri khas adanya pesan berupa instruksi tugas atau perintah kerja.

Manajer Area selaku pemegang otoritas tertinggi tidak menggunakan kegiatan Code of Conduct sebagai tempatnya untuk mengeluarkan instruksi tugas, melainkan hanya melakukan pembahasan bdengan memberikan saran dan kesimpulan yang dirasa dibutuhkan oleh karyawan secara keseluruhan. Pemberian saran dan kesimpulan ini dapat diartikan sebagai pandangan Manajer Area terhadap permasalahan yang diangkat oleh bagian pelaksana kegiatan Code of Conduct dalam knowledge sharing. Terkadang dalam pelaksanaan pekerjaan di lapangan, karyawan menemui kendala-kendala yang menghambat penyelesaian pekerjaan, untuk itu peran Manajer Area dalam memberikan saran kepada karyawan sangat dibutuhkan.

Komunikasi ke atas adalah ketika informasi bergerak dari merka dengan tingkatan lebih rendah kepada mereka yang memiliki tingkatan lebih tinggi dalam struktur organisasi perusahaan. Sama halnya dengan komunikasi ke bawah, dalam kegiatan Code of Conduct karyawa menganggap bahwa tidak ada komunikasi ke atas selama kegiatan tersebut berlangsung. Hal tersebut diperjelas bahwa dalam kegiatan Code of Conduct tidak ada proses memerintah dan tidak ada proses diperintah. Komunikasi ke atas berlangsung secara formal karena melewati rantai formal organisasi, sementara kegiatan Code of Conduct adalah suatu kegiatan yang tidak menganut komunikasi secara formal karena dalam pelaksanaannya karyawan dapat melakukan komunikasi secara bebas, terbuka, dan melewati batasan tingkatan sehingga komunikasi ke atas pun dianggap tidak terjadi dalam kegiatan Code of Conduct.

Komunikasi horizontal adalah informasi yang bergerkan di antara rekan sekerja atau unit-unit kerja yang berbeda. Dalam kegiatan Code of Conduct, komunikasi horizontal merupakan komunikasi yang satu-satunya terjadi menurut pandangan karyawan PLN (Persero) Area Bandung. Hal tersebut karena tujuan pelaksanaan kegiatan Code of Conduct adalah meningkatkan koordinasi antara bagaian fungsional dengan bagian fungsional lainnya, membuat komunikasi yang paling dominan terjadi adalah komunikasi antara rekan sekerja atau unit-unit kerja yang ada di PLN (Persero) Area Bandung. Koordinasi yang merupakan bentuk komunikasi ke bawah yang dilakukan dalam kegiatan Code of Conduct adalah (1) menyatukan pemahaman atau persepsi karyawan PLN (Persero) Area Bandung agar tidak ada lagi kesalahan pemahaman terhadap pekerjaan, (2) koordniasi yang menyangkut dengan tata cara pelaksaan pekerjaan di lapangan yang notabene adalah kerjasama antar bagian fungsional.

Dalam kegiatan Code of Conduct, karyawan bebas memberikan tanggapan apapun selama sifatnya masih memiliki keterkaitan dengan topik pembahasan dalam knowledge sharing. Komunikasi seperti itu memungkinkan suasana menjadi lebih aktif karena semua karyawan dapat terlibat dalam proses komunikasi. Tanggapan tidak hanya dari pihak peserta kepada pihak pelaksana saja tetapi juga bisa antara peserta dengan peserta. Dengan seperti itu komunikasi dalam kegiatan Code of Conduct memungkinkan siapa saja untuk berbicara tanpa adanya tokoh sentral atau tokoh utama yang mengatur keseluruhan proses komunikasi yang terjadi dalam kegiatan Code of Conduct .

Dalam kegiatan Code of Conduct, tidak ada tokoh sentral di mana semua pokokpokok pembicaraan terpusat hanya seorang kepadanya dikarenakan komunikasi organisasi dalam kegiatan Code of Conduct membebaskan semua karyawan untuk mengeluarkan suara baik dalam bentuk pemberian tanggapan berupa menyetujui apa yang dibicarakan oleh bagian pelaksana kegiatan, mengajukan pertanyaan yang berkaitan dengan pokok pembicaraan dalam kegiatan Code of Conduct, pemberian gagasan atau ide yang dapat digunakan untuk mempermudah prosedur pengerjaan di lapangan, dan juga pemberian saran yang dirasa sangat dibutuhkan oleh bagian fungsional tertentu baik yang berperan sebagai pelaksana kegiatan atau yang sedang tidak berperan sebagai pelaksana kegiatan atau yang disebut peserta kegiatan.

Dengan seperti itu sudah jelas bahwa komunikasi dalam kegiatan Code of Conduct memilki arus komunikasi yang membebaskan seluruh karyawan dalam melakukan komunikasi secara timbal balik tanpa menganut siapa yang menjadi tokoh sentralnya. Hal tersebut dikarenakan karyawan bersifat aktif dalam 
pemberian tanggapan yang menyebabkan komunikasi organisasi terjadi secara bebas dan menyeluruh.

Kegiatan Code of Conduct PT. PLN (Persero) Area Bandung adalah sebuah kegiatan rutin dimana karyawan bersamasama melakukan pembahasan mengenai pekerjaan atau hal-hal lainnya yang memiliki kaitannya dengan PT. PLN (Persero) Area Bandung secara keseluruhan. Selayaknya kegiatan yang membicarakan tentang pekerjaan maka komunikasi yang baik dan jelas sangat dibutuhkan dalam kegiatan ini. Komunikasi yang baik akan sangat berpengaruh terhadap kelancaran proses komunikasi selama kegiatan Code of Conduct berlangsung.

Kegiatan Code of Conduct PT. PLN
(Persero) Area Bandung mengalami perubahan konsep yang awalnya ditujukan untuk menginternalisasikan atau menyosialisasikan kepada karyawan tentang pedoman perilaku dan nilai-nilai perusahaan menjadi sebuah kegiatan yang dilakukan untuk meningkatkan komunikasi dan koordinasi seluruh karyawan guna menyatukan pemahaman tentang pekerjaan dalam menyelesaikan pekerjaan. Selaras dengan yang disampaikan oleh Bapak Dony, selaku Supervisore Administrasi Umum PT. PLN (Persero) Area Bandung yang menyatakan bahwa kegiatan Code of Conduct banyak mengalami perubahan.

Komunikasi ke bawah dalam kegiatan Code of Conduct terjadi jika yang sedang melakukan pembicaraan adalah Manajer Area. Pesan

\section{Tabel 3 Sejarah Kegiatan Code of Conduct}

Tahun 2009

OPI (Operation Performance Improvement) region Jawa dan Bali memiliki kenginan membentuk PT. PLN (Persero) menjadi perusahaan listrik terbesar Asia Tenggara mengalahkan perusahaan listrik Malaysia, yaitu PMB.

Tahun 2010

Terbentuknya kegiatan internalisasi tata nilai perusahaan dan do \& don't perusahaan.

Adanya kebutuhan karyawan akan sebuah wadah atau forum yang melibatkan seluruh karyawan untuk melakukan pembahasan mengenai pekerjaan dan hal-hal terkait lainnya dengan perusahan.

Terbentuknya kegiatan untuk mendiskusikan perihal pekerjaan, seperti kendala saat bertugas di lapangan,

Tahun 2014 kinerja pekerjaan, dan sosialisasi mengenai kegiatan perusahaan.

Sumber: Hasil penelitian 2016

Tabel 4 Konsep Kegiatan Code of Conduct

Konsep Kegiatan

Code of Conduct Dulu

Konsep Kegiatan

Code of Conduct Sekarang
Melakukan internalisasi atau sosialisasi kepada seluruh karyawan mengenai nilai-nilai perusahaan PLN (Persero) yaitu Saling Percaya, Integritas, Peduli dan Pembelajar yang didalamnya terdapat apa yang harus dilakukan dan tidak boleh dilakukan oleh karyawan PT. PLN (Persero).

Mengumpulkan seluruh karyawan ke dalam ruang dan waktu yang sama untuk sama-sama melakukan diskusi atau dikenal dengan knowledge sharing. Knowledge sharing ini dapat berupa pembahasan apapun baik tentang pekerjaan atau hal lain yang masih berkaitan dengan pekerjaan. 
Tabel 5 Inti Pembahasan Kegiatan Code of Conduct

Inti Pembahasan
Kegiatan Code of Conduct Dulu

Inti Pembahasan Kegiatan

Code of Conduct Sekarang
Mengangkat tema-tema menarik yang memiliki relevansi dengan nilai-nilai perusahaan PLN (Persero), yaitu Saling Percaya, Integritas, Peduli dan Pembelajar.

Pembahasan tidak lagi hanya tentang tata nilai perusahaan PLN (Persero) melainkan pembahasan yang dilakukan berkisar tentang pekerjaan karyawan dan hal-hal yang memiliki keterkaitan dengan aktivitas atau pekerjaan karyawan lainnya.

Sumber: Hasil penelitian, 2016

Tabel 6 Tujuan Kegiatan Code of Conduct

Tujuan Kegiatan Code of Conduct Dulu

Tujuan Kegiatan Code of Conduct Sekarang
- Mengingatkan karyawan terhadap nilai-nilai perusahaan dan pedoman perilaku yang dimiliki oleh PLN (Persero).

- Membentuk karyawan yang berorientasi terhadap perusahaan dan pelanggan di setiap pelaksanaan pekerjaannya.

- Menyamakan persepsi atau cara pandang karyawan terhadap pekerjaan.

- Meningkatkan komunikasi untuk seluruh karyawan untuk memperlancarnya jalannya aktivitas dan peekrjaan perusahaan guna dapat mencapai pencapain-pencapaian yang sudah ditetapkan.

- Meningkatkan koordinasi antar bagian fungsional mengenai pekerjaan yang akan dilakukan.

Sumber: Hasil penelitian, 2016

yang termasuk dalam komunikasi ke bawah adalah rasio kerja dan umpan balik. Rasio kerja adalah ketika Manajer Area melakukan pembahasan yang berisi tentang kesimpulan atau saran yang pada akhirnya menghasilkan pemahaman karyawan terhadap pekerjaan yang harus mereka kerjakan. Sementara umpan balik adalah tipe pesan penyampaian apresiasi terhadap kinerja karyawan PLN (Persero) Area Bandung. Gambar 2 menggambarkan komunikasi ke bawah dalam kegiatan Code of Conduct PT. PLN (Persero) Area Bandung.

Komunikasi ke atas dalam kegiatan Code of Conduct terjadi jika yang menjadi pembicara adalah karyawan yang menjabat sebagai bagian Fungsional. Jabatan Fungsional menggunakan kegiatan Code of Conduct sebagai saat yang tepat untuk memberitahu tentang pencapaian- pencapaian yang telah mereka dapat dari apa yang sudah mereka kerjakan.

Komunikasi ke atas dalam kegiatan Code

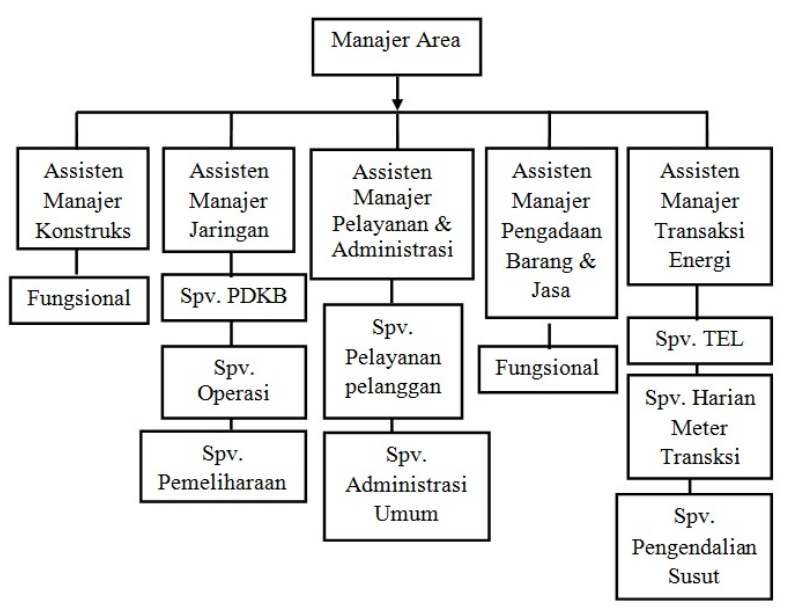

Gambar 2 Komunikasi ke Bawah dalam Kegiatan Code of Conduct 
of Conduct PT. PLN (Persero) Area Bandung lebih bersifat laporan kepada atasan bahwa karyawan sudah melakukan pekerjaan dengan baik. Gambar 3 menggambarkan komunikasi ke atas dalam kegiatan Code of Conduct PT. PLN (Persero) Area Bandung.

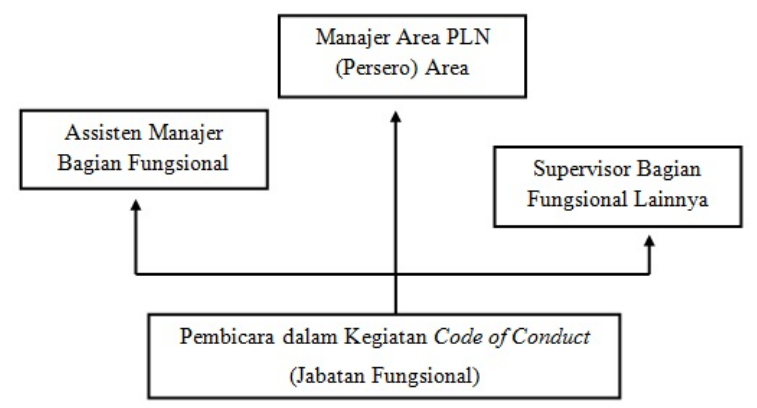

\section{Gambar 3 Komunikasi ke Atas dalam} Kegiatan Code of Conduct

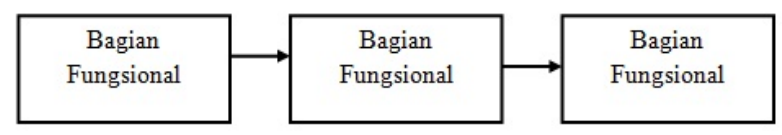

\section{Gambar 4 Komunikasi Horizontal dalam Kegiatan Code of Conduct}

Komunikasi horizontal dalam kegiatan Code of Conduct terjadi jika pembahasan yang dilakukan karyawan bertujuan untuk melakukan koordinasi antar bagian fungsional satu dan bagian fungsional lainnya. Koordinasi yang dilakukan dalam kegiatan Code of Conduct berguna untuk menyatukan pemahaman seluruh karyawan terhadap pekerjaan yang dilakukan oleh bagian fungsional tertentu dan juga koordinasi langsung berupa kerjasama yang dibutuhkan untuk menyelesaikan pekerjaan dengan baik dan cepat. Koordanasi dalam kegiatan Code of Conduct juga berguna untuk meningkatkan komunikasi seluruh karyawan guna memperlancar pengerjaan pekerjaan sehingga dapat meningkatkan kinerja karyawan.

Selain komunikasi sesuai rantai formal, komunikasi dalam kegiatan Code of Conduct PLN (Persero) Area Bandung berjalan di luar rantai formal atau yang disebut dengan komunikasi informal, pribadi dan selentingan. Komunikasi informal dalam kegiatan Code of Conduct adalah ketika dua karyawan atau lebih telibat perbincangan di luar dari pembahasan knowledge sharing yang dibahas oleh bagian pelaksana dan karyawan lainnya. Komunikasi informal yang sering dilakukan oleh karyawan lebih kepada masalah-masalah sosial yang dialami oleh karyawan, sebagai contohnya adalah sekedar membicarakan hubungan karyawan satu sama lainnya.

Setelah mengetahui komunikasi organisasi PT. PLN (Persero) Area Bandung dalam kegiatan Code of Conduct melalui arah aliran informasi organisasi, maka peneliti akan menggambarkan komunikasi organisasi pada kegiatan Code of Conduct PT. PLN (Persero) Area Bandung ke dalam pola jaringan komunikasi organisasi. Pola jaringan komunikasi organisasi ini berguna untuk memberikan gambaran lebih jelas tentang alur komunikasi yang sesungguhnya terjadi dalam kegiatan Code of Conduct yang melibatkan seluruh karyawan PT. PLN (Persero) Area Bandung.

Sementara itu, untuk Pola komunikasi organisasi yang terjadi adalah pola komunikasi saluran bebas (all channel). Pola komunikasi organisasi saluran bebas (all channel) terjadi karena komunikasi berlangsung secara terbuka dan bebas dengan melibatkan seluruh karyawan dengan tingkatan jabatan berbeda yaitu Manajer Area, Assisten Manajer, Supervisor dan Fungsional. Komunikasi terbuka dan bebas memungkinkan seluruh karyawan bebas mengutarakan pendapatnya selagi hal tersebut berhubungan dengan topik pembahasan knowledge sharing yang telah disampaikan oleh pelaksana kegiatan. Selain itu, komunikasi berlangsung secara menyeluruh di mana seluruh karyawan dapat melakukan interaksi dengan siapapun tanpa memperhatikan posisi mereka dalam jabatan struktural dan tanpa juga memperhatikan jabatan lawan berbicaranya dalam struktur organisasi, sehingga karyawan dapat secara bebas dan terbuka pula dalam memberikan umpan balik. Penggambaran pola komunikasi organisasi saluran bebas (all channel) dalam kegiatan Code of Conduct PT. PLN (Persero) Area Bandung ditunjukkan oleh Gambar 5.

Pada gambar 5 terlihat bahwa komunikasi dalam kegiatan Code of Conduct yang melibatkan seluruh karyawan terjadi secara bebas, menyeluruh dan dua arah tanpa dibatasi antar tingkat jabatan struktural. Hal itu selaras dengan pemaparan teori tentang pola jaringan saluran bebas.

Pola jaringan saluran bebas (all channel) menurut Ruliana (2014: 81), merupakan pola jaringan yang mengizinkan semua anggota 


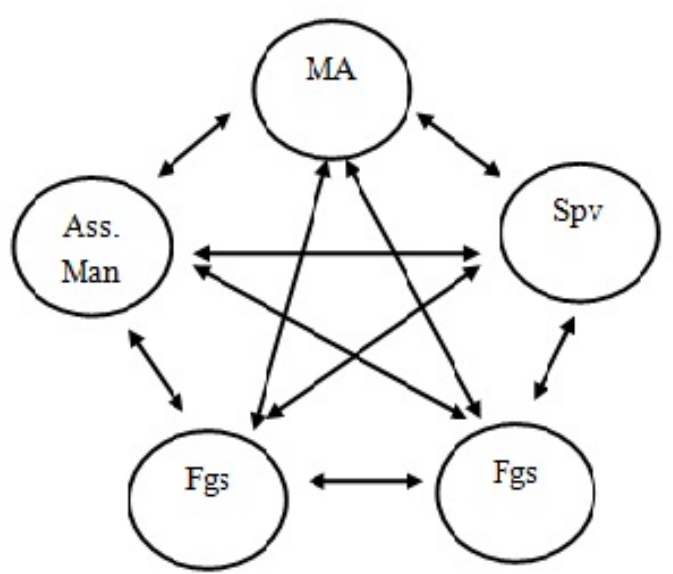

\section{Gambar 5 Komunikasi Horizontal dalam Kegiatan Code of Conduct}

komunikasi secara aktif melakukan komunikasi. Dalam pola jaringan saluran bebas ini dapat terjadi komunikasi lanjutan di antara semua tingkatan yang terlibat tanpa adanya batasan komunikasi pertingkatannya seperti pola lingkaran.

Pola jaringan saluran bebas (all channel) menggambarkan tentang tiga tingkatan atau lebih yang ada dalam organisasi di mana semua tingkatan dapat berkomunikasi satu sama lainnya. Ciri khas dari pola jaringan saluran bebas adalah komunikasi terjadi secara dua arah di mana seluruh pihak terlibat dalam proses komunikasi. Komunikasi bersifat informatif dan persuasif sehingga memerlukan umpan balik dari pihak-pihak yang terlibat.

Karyawan dalam kegiatan Code of Conduct PT. PLN (Persero) Area Bandung memiliki tanggung jawab sebagai pelaksana kegiatan dan peserta kegiatan, di mana pelaksana diharuskan melakukan penjelasan terhadap materi knowledge sharing kepada peserta kegiatan lainnya. Sementara karyawan selaku peserta kegiatan aktif memberikan tanggapan berupa memberikan saran atau mengajukan pertanyaan terhadap materi knowledge sharing yang dipilih oleh bagian pelaksana.

Di kegiatan Code of Conduct peserta kegiatan dapat dengan bebas mengajukan pertanyaan atau memberikan saran untuk kemudian ditujukan kepada jabatan apapun yang ada di bagian pelaksana kegiatan Code of Conduct pada saat itu. Hal tersebut berarti komunikasi dapat terjadi dengan melewati tingkatan struktural perusahaan di mana karyawan tidak membatasi dirinya hanya melakukan komunikasi pada tingkatan tertentu.
Pola jaringan saluran bebas terjadi karena dalam kegiatan Code of Conduct PT. PLN (Persero) Area Bandung komunikasi bertujuan untuk meningkatkan koordinasi antara seluruh karyawan PT. PLN (Persero)Area Bandung, oleh karena itu diskusi bersama mengenai pekerjaan sangat terlihat dalam kegiatan Code of Conduct PT. PLN (Persero) Area Bandung. Selayaknya diskusi maka memerlukan keikutsertaan seluruh karyawan dan tidak diperbolehkan adanya batasan komunikasi karena akan mengurangi efektivitas diskusi yang sedang dilakukan. Diskusi juga membutuhkan tanggapan segera dari seluruh pihak yang terlibat karena diskusi sifatnya membutuhkan hasil dengan segera sehingga karyawan harus memberikan tanggapannya terhadap pembahasan knowledge sharing dalam kegiatan Code of Conduct.

\section{SIMPULAN}

Simpulan yang dapat diambil dari penelitian ini adalah (1) kegiatan Code of Conduct PT. PLN (Persero) Area Bandung adalah kegiatan menyampaikan informasi yang berkaitan dengan pekerjaan dengan tujuan meningkatkan komunikasi serta koordinasi seluruh karyawan agar pekerjaan dapat selesai dengan cepat dan tepat. (2) Arah aliran informasi berlangsung secara komunikasi ke atas, komunikasi ke bawah, komunikasi horizontal, dan komunikasi pribadi. (3) Pola komunikasi organisasi yang terbentuk adalah pola komunikasi saluran bebas (all channel).

Sedangkan saran yang peneliti ajukan adalah (1) koordinasi pekerjaan seperti dalam kegiatan Code of Conduct sangat memegang peranan penting dalam menyelesaikan tugas, oleh karena itu peningkatan komunikasi yang terorganisir sangat dibutuhkan. (2) Kesadaran karyawan dalam mendengarkan pembicara perlu ditingkatkan agar tidak terjadi kesalahan dalam pemahaman informasi yang diterima.

\section{DAFTAR PUSTAKA}

Buku Company Profile. (2011). Jakarta: PLN (Persero)

Buku Pedoman Perilaku. (2010). Jakarta: PLN (Persero)

Admin. (2014). Inilah daftar perusahaan BUMN terbaik di Indonesia. Diakses 8 Februari 2014 dari http://www.invonesia. 
com/daftar-perusahaan-bumn-terbaik. html

Adam, M \& Budiawati, A.D. (2014). PLN masuk peringkat fortune 500. Diakses 10 Juli 2014 dari http://m.viva.co.id/berita/ bisnis/520218-pln-masuk-peringkatfortune-500

Irawan, D. \& Venus, A. (2016). Pengaruh iklim komunikasi organisasi terhadap kinerja pegawai kantor keluarga berencana Jurnal Kajian Komunikasi, 4/2, 122-132

Komariah, K., Perbawasari, S., Nugraha, A. R., \& Budiana, H. R. (2013). Pola komunikasi kesehatan dalam pelayanan dan pemberian informasi mengenai penyakit tbc pada puskesmas di kabupaten bogor. Jurnal Kajian Komunikasi, 1/2, 173-185

Miftah, M. N., Rizal, E., \& Anwar, R. K. (2016). pola literasi visual infografer dalam pembuatan informasi grafis (infografis). Jurnal Kajian Informasi Dan Perpustakaan, 4(1), 87-94
Nasrullah, R. (2014). Teori dan riset media siber (cybermedia). Jakarta: Prenada Media Grup

Nuland, S. V. \& Khandelwal, B. P. (2009). Ethics in education: the role of teacher codes canada and south asia. Paris: Internation Institute for Educational Planning

Nurussa'adah, E. \& Sumartias, S. (2017). Komunikasi politik partai keadilan sejahtera (pks) dalam keterbukaan ideologi 1. Jurnal Kajian Komunikasi, $5 / 1,43-52$

Pace, R. W. \& Faules, D. F. (2006). Komunikasi organisasi. Bandung: Remaja Rosdakarya

Rakhmat, J. (2009). Metode penelitian kualitatif. Bandung: Remaja Rosdakarya

Ruliana, P. (2014). Komunikasi organisasi: teori dan studi kasus. Jakarta: Rajawali Pres

Sugiyono. (2014). Memahami penelitian kualitatif. Bandung: Alfabeta Bandung 